\title{
Urgensitas Ulama dan Dakwah Islamiyyah dalam Meningkatkan Pemberdayaan Masyarakat (Ambigu Antara Idealitas Dan Realitas)
}

\author{
Oleh: \\ Dr. A.R. Idhamkholid. S.Ag. M.Ag. 1 \\ Kholididham17@yahoo.com
}

\begin{abstract}
Abstrak
Masyarakat Modern dengan segudang kesibukan yang selalu melilitnya telah berada diujung kehidupan yang "pemisahan yang dalam" antara si kaya dan si miskin. Yang kaya semakin kaya dan yang miskin semakin miskin. Kemiskinan yang teramat sangat ataupun kekayaan yang berlebihan bisa menempatkan manusia pada kondisi yang tak seimbang. Karena itu perlu diadakan penyadaran lewat dakwah Islamiyyah oleh para ulama. Dengan dakwah Islamiyyah diharapka bai8k si kaya maupun si miskin bisa saling toleran dan saling menimbang rasa. Terutama si miskin perlu dipahamkan bahwa kemiskinan bukan memicu munculnya sikap ketidak berdayaan ataupun bukan akhir dari segalanya dalam hidup ini. Karena masih banyak hal yang bisa dilakukan oleh si miskin dalam kehidupan ini. Si miskin perlu diberdayakan agar lebih bisa membantu dirinya sendiri.
\end{abstract}

Kata Kunci: Ulama, Dakwah islamiyyah dan Pemberdayaan masyarakat

\section{Abstract}

Modern society with a myriad of activities that always wrapped around it has been at the end of life a "deep separation" between the rich and the poor. The rich get richer and the poor get poorer. Extremely poverty or excessive wealth can put people in an unbalanced state. Therefore it is necessary to establish awareness through Islamiyyah dakwah by the scholars. With Islamiyyah dakwah expected bai8k the rich and the poor can be mutual tolerance and mutual taste. Especially the poor need to be understood that poverty does not trigger the emergence of the attitude of helplessness or not the end of everything in life. Because there are still many things that the poor can do in this life. The poor need to be empowered to be more able to help himself.

Keywords: Ulama, Islamiyyah Da'wah and Community Empowerment

\footnotetext{
1 Penulis adalah dosen Fakultas Ushuluddin Adab dan Dakwah (FUAD) Prodi Filsafat Islam dan Program Pascasarjana Institut Agama Islam (IAIN) Syekh Nurjati Cirebon Jawa Barat.
} 
menjawab segala tantangan zaman, khususnya yang berhubungan dengan ilmu keislaman. Al-Qur'an menempatkan ulama pada martabat yang mulia. Sebagai pewaris nabi, ${ }^{2}$ mereka bertanggung jawab mengayomi segenap umat pada zamannya. ${ }^{3}$

Dalam menghadapi realitas yang demikian, tentu menjadi urgen hadirnya ulama dan dakwahnya dalam upaya meningkatkan kewaspadaan ummat dan meningkatkan pemberdayaan masyarakat. Pemberdayaan ini hakikatnya membangun sumber daya manusia untuk dapat hidup lebih baik dan sejahtera sesuai dengan kebutuhan, potensi dan budaya mereka. ${ }^{4}$

Dakwah dalam realitas sehari-hari telah dipahami dalam pengertian yang luas. Menurut HMS Nasarudin Latif sebagaimana dikutip oleh Moh. Ali Aziz, dakwah adalah setiap usaha atau aktivitas dengan lisan atau tulisan yang bersifat menyeru, mengajak, memanggil manusia lainnya untuk beriman dan menaati Allah Swt., sesuai dengan garis-garis aqidah dan syari'ah serta akhlak islamiyah.

Mengacu pada pengertian dan pemahaman tentang dakwah tersebut, maka dakwah harus dikemas sedemikian rupa dan dintmuskan secara matang untuk mewujudkan masyarakat yang menjalankan nilai-nilai Islam dalam artian luas. Dakwah bukanhanya sekedar menyampaikan seperangkat tata cara beribadah (mahdlah) kepada Tuhan, tetapi

2 Al-Quran membagi para pewaris Kitab Suci ke dalam tiga kategori: (a) menganiaya diri mereka; (b) pertengahan; dan (c) lebih dahulu berbuat kebaikan (QS 35:32). Lihat Quraish Shihab. Membumikan Al-Quran

${ }^{3}$ Badruddin HSubky. Dilema Ulama dalam Perubahan Zaman Jakarta: Gema Insani Press. 1995., hlm., 22

4 Haryono Suyono Kata Pengantar. Dalam Oos M. Anwas. Pemberdayaan Masyarakat di Era Global. Bandung : Alfabeta. 2014., hlm., iv.

\section{A. PENDAHULUAN}

Era modern dan global merupakan era yang penuh tantangan dan ancaman bagi umat Islam, khususnya kalangan ulama. Era ini ditandai oleh pesatnya perkembangan ilmu pengetahuan, teknologi, proses industrialisasi, serta adanya pergeseran dan perubahan tata nilai serta budaya.

Seluruh perkembangan itu ditunjang oleh informasi yang datang lewat berbagai saluran. Arus informasi ini - terutama yang datang melalui media massamenimbulkan benturan antara nilai-nilai budaya asing dengan nilai-nilai budaya bangsa Indonesia yang mayoritas muslim. Benturan kedua nilai budaya tersebut menghasilkan kompromi budaya. Selanjutnya, terbentuklah suatu kemajemukan budaya, baik yang bercorak negatif maupun positif.

Pada kenyataannya, tidak sedikit dampak positif yang ditimbulkan oleh derasnya arus informasi. Namun, tidak sedikit pula akibat negatifnya, seperti munculnya berbagai tindak pelanggaran dan penyelewengan. Bentuknya sangat beragam, antara lain sadisme, pornografi, pelacuran, perkosaan, penyalahgunaan narkotika, dan perjudian. Selain itu, kontrol sosial melemah sedangkan budaya permisifisme, hedonisme, konsumerisme, korupsi, dan ketidakpedulian sosial semakin meluas. Begitu pula, berbagai faham dari luar, seperti materialisme dan sekularisme, semakin menggeser nilainilai keislaman yang luhur. Demikian pula kapitalisme dan hedonisme yang bersumber dari faham liberalisme Barat. Umat Islam, khususnya kalangan ulama, harus mampu bersikap cepat dan tanggap dalam menghadapi problema besar ini.

Hal ini mengingat karena sejak kelahirannya, ulama merupakan figur sentral di tengah-tengah umat. Ulama di Indonesia -yang mayoritas adalah alumnus pcsantren,-_ merupakan tumpuan harapan masyarakat untuk 
Di kalangan umat Islam, kata ulama mcnimbulkan berbagai persepsi sehingga belum ada definisi yang baku.

Dalam upaya merumuskan kata ulama, menurut badrudin HSubky hendaknya merujuk kepada pendapat para mufassir salaf (sahabat dan tabi'in) yang dekat dengan pusat ilmu keislaman.Beberapa di antara pendapat mereka disajikan berikut ini. Rumusan ini diakui kcabsahannya oleh sebagian besar pimpinan pesantren di Indonesia.

a. Imam Mujahid : "Ulama adalah orang yang hanya takut kepada Allah SWT." Malik bin Anas pun menegaskan, "Orang yang tidak takut kepada Allah bukanlah ulama."

b. Hasan Basri : "Ulama adalah orang yang takut kepada Allah disebabkan perkara gaib, suka kepada setiap sesuatu yang disukai Allah, dan menolak segala sesuatu yang dimurkaiNya."

c. Ali ash-Shabuni : "Ulama adalah orang yang rasa takumya kepada Allah sangat mendalam disebabkan ma'rifatnya."

d. Ibnu Katsir: "Ulama adalah yang benarbenar ma'rifatnya kepada Allah sehingga mereka takut kepada-Nya. Jika ma'rifatnya sudah sangat dalam maka sempurnalah takutnya kepada Allah."

e. Sayyid Quthub : "Ulama adalah orang yang senantiasa berpikir kritis akan Kitab Al-Qur'an (yang mendalam maknanya) sehingga mereka akan ma'rifat secara hakiki kepada Allah. Mereka ma'rifat

\footnotetext{
hakiki hanya para nabi karena ma'rifatnya kepada Allah sangat mendalam.

Pendapat mufassir itu menunjukkan, khasyyah merupakan kriteria khusus bagi seorang ulama. Namun demikian, sulit menemukan kriteria ulama yang komprehensif.

10 Badruddin HSubky. Dilema

Ulama., Op., Cit., hlm., 44
}

dakwah yang mencerahkan sesuai dengan prinsip dasar Islam (tauhid), memberikan motivasi, dan juga membangun sistem atau struktur sosial yang memungkinkan orang saling mengingatkan dalam kerangka menjalankan nilai-nilai Islam tersebut. $^{5}$

\section{A. ULAMA \\ 1. Pengertian Ulama.}

Al-Quran mengukir kata ulama sebanyak dua kali yaitu dalam surat asySyu'ara' ayat 197 dan Faathir ayat 28.

Artinya: "Dan apakah tidak cukup menjadi bukti bagi mereka bahwa para ulama Bani Israil mengetahuinya?"6

Artinya: Sesungguhnya yang takut kepada Allah di antara hamba-hambaNya, hanyalah ulama. ${ }^{7}$ Sesungguhnya Allah Maha Perkasa lagi Maha Pengampun. $^{8}$

Ayat di atas menurut badrudin HSubky mengisyaratkan bahwa ulama merupakan hamba Allah yang beriman, bertakwa, menguasai ilmu kauniyah dan tanziliyah, berpandangan hidup luas, dan bcribadah dengan landasan rasa takut kepada Allah SWT. Takut (khasyyah), ${ }^{9}$ merupakan sifat khusus ulama. ${ }^{10}$

5 Ropingi el-Ishaq. Pengantar Ilmu Dakwah Studi Komprehendif Dakwaj dari Teori ke Praktik. Malang: Madani. 2016., hlm., 184

${ }^{6}$ QS. asy-Syu'ara': 197.

7 Yang dimaksud dengan ulama dalam ayat Ini ialah orang-orang yang mengetahui kebesaran dan kekuasaan Allah.

${ }^{8}$ QS. Faathir: 28

9 Sejumlah mufassir menjelaskan pengertian kata khasyyah dalam kitab tafsir mereka masing-masing. Said bin Jubair mengatakan bahwa khasyyah adalah rasa takut kepada Allah yang menghalangi seseorang dari perbuatan dosa kcpada-Nya. Menurut Ali Husain al-Jurjani, khasyyah ialah rasa takut pada tindakan yang dibenci Allah. Khasyyah muncul jika seseorang merasa ia melakukan banyak dosa atau mendapat pengaruh ma'rifat dari Allah SWT Yang bisa khasyyah kepada Allah secara 
perbuatan positif, bertanggung jawab, dan istiqamah.

e. Berjiwa besar, kuat mental dan fisik, tahan uji, hidup sederhana, amanah, beriradah, berjamaah, tawadhu', kasih sayang terhadap sesama, mahabah, serta khasyyah dan tawakal kepada Allah SWT.

f. Mengetahui dan peka terhadap situasi zaman serta mampu menjawab setiap persoalan untuk kepentingan Islam dan umatnya.

g. Berwawasan luas dan menguasai beberapa cabang ilmu demi pengembangannya. Menerima pendapat orang lain yang tidak bertentangan dengan Islam dan bersikap tawadhu'. ${ }^{14}$

Nampaknya, definisi di atas belum dikenal secara luas oleh umat Islam. Sebab, di tengah masyarakat berlangsung kebiasaan mcmberikan gelar ulama kepada seseorang yang belum memenuhi kriteria di atas.

Kenyataan yang demikian menurut hemat penulis menjadi salah satu sebab sering ditemukannya ulama yang kurang kredibel karena begitu mudahnya orang memberi gelar ulama pada orang yang belum memiliki kriteria yang cukup untuk dapat dianggap sebagai ulama.

\section{Tipologi Ulama}

Sejak kelahiran Islam sampai dewasa ini, eksistensi ulama tetap diakui. Namun demikian, pengertian ulama yang baku belum ditemukan. Akibatnya, penggunaan kata ulama yang tidak sesuai dengan Al-Qur'an dan As-Sunnah masih sering ditemukan di tengah masyarakat.

Terkait dengan masalah tipologi ulama, Badrudin HSubky mensinyalir bahwa di tengah masyarakat dewasa ini dikenal lima macam ulama, yaitu ulama plus, ulama pulus, ulama dunia, ulama akhirat, dan ulama dunia akhirat. Sosok

\footnotetext{
${ }^{14}$ Ibid.,, hlm., 47
}

f. Syekh Nawawi al-Bantani : "Ulama adalah orang-orang yang menguasai segala hukum syara' untuk menetapkan sahnya agama, baik penetapan sah i'tikad maupun amal syari'at Iainnya." Sedang-kan Dr. Wahbah az-Zuhaili bcrkata, "Secara naluri, ulama adalah orang-orang yang mampu menganalisa alam fenomena untuk kepentingan hidup dunia dan akhirat serta takut ancaman Allah jika terjerumus ke dalam kenistaan. Orang yang maksiat hakikatnya bukan ulama.". 11

g. M. Quraish Shihab: Ulama ialah orang yang mempunyai pengetahuan tentang ayat-ayat Allah, baik yang bersifat kawniyyah maupun yang bersifat qur'aniyyah. $^{12}$

\section{Kriteria Ulama}

Ulama sebagai pewaris Nabi mempunyai tugas dan tanggung jawab yang besar dalam membimbing mengayomi segenap umat pada zamannya. ${ }^{13}$ Oleh karena itu tidak setiap orang begitu mudahnya mengklaim dirinya sebagai ulama. Seorang yang dianggap sebagai ulama setidaknya harus memiliki kriteria sebagai berikut:

a. Menguasai ilmu agama Islam (fafaqquh fiddin) dan sanggup membimbing umat dengan memberikan bekal ilmu-ilmu ke-islaman yang bersumber dari AlQur'an, hadits, ijma', dan qiyas.

b. Ikhlas melaksanakan ajaran Islam.

c. Mampu menghidupkan Sunnah Rasul dan mengembangkan Islam secara kaffah.

d. Berakhlak luhur, berpikir kritis, aktif mendorong masyarakat melaku-kan

${ }_{11}^{11}$ Ibid., hlm., 45-46
${ }^{12}$ M. Quraish Shihab. Membumikan Al-Quran: Fungsi dan Peran Wahyu dalam Kehidupan Masyarakat. Bandung : Mizan. 1992., hlm 382

13 Badruddin HSubky. Dilema

Ulama., Op., Cit., hlm., 22 
untuk melaksanakan ajaran Islam secara menyeluruh.

Imam Ghazali mengemukakan dua macam ulama di dunia yaitu ulama akhirat dan ulama dunia (ulama su'). Dengan rinci ia mengemukakan tanda-tanda ulama dengan argumentasi absah. Tanda-tanda ulama akhirat adalah:

1. Tidak mencari kemegahan dunia dengan menjual ilmunya dan tidak mem-perdagangkan ilmunya untuk kepentingan dunia.

Artinya:Dan Sesungguhnya diantara ahli Kitab ada orang yang beriman kepada Allah dan kepada apa yang diturunkan kepada kamu dan yang diturunkan kepada mereka sedang mereka berendah hati kepada Allah dan mereka tidak menukarkan ayatayat Allah dengan harga yang sedikit. mereka memperoleh pahala di sisi Tuhannya. Sesungguhnya Allah amat cepat perhitungan-Nya.

2. Perilakunya sejalan dengan ucapannya dan tidak menyuruh orang berbuat kebaikan sebelum ia mengamalkannya. ${ }^{18}$

3. Mengajarkan ilmunya untuk kepentingan akhirat, senantiasa mendalami ilmu pengetahuan yang dapat mendekatkan dirinya kepada Allah SWT, dan menjauhi segala perdebatan yang sia-sia.

4. Mengcjar kehidupan akhirat dengan mengamalkan ilmunya dan menunaikan berbagai ibadah.

5. Menjauhi godaan penguasa jahat. Sabda Nabi saw., "Sejahat-jahatnya ulama ialah yang mendatangi penguasa dan sebaik-baik penguasa adalah yang mendatangi ulama.". ${ }^{19}$

6. Tidak ccpat mengcluarkan fatwa sebelum ia menemukan dalilnya dari Al-Qur'an dan As-Sunnah. Jika ia

\footnotetext{
${ }^{18}$ QS Al-Baqarah: 44.

${ }^{19}$ HR Ibnu Majah.
}

ulama yang terakhir ini sangat dibutuhkan umat karena ia mampu menuntun masyarakat kepada kebahagiaan di dunia dan akhirat. ${ }^{15}$

Meskipun peran ulama sangat penting, segolongan masyarakat berupaya mendiskreditkannya dengan berbagai macam cara. Mereka berusaha memperkecil peranannya, bahkan menghilangkannya sama sekali. Ada pula yang ingin menggeser kedudukan ulama dengan berbagai tindakan yang sangat bertentangan dengan ajaran Islam.

Ironisnya, mereka yang ingin menggeser ulama itu adalah ulama ju-ga. Mereka betlaku zalim terhadap diri sendiri. Disebutkan dalam Al-Qur'an:

Artinya : Kemudian Kitab itu kami wariskan kepada orang-orang yang kami pilih di antara hamba-hamba kami, lalu di antara mereka ada yang menganiaya diri mereka sendiri, ${ }^{16}$ dan di antara mereka ada yang pertengahan dan diantara mereka ada (pula) yang lebih dahulu berbuat kebaikan dengan izin Allah. yang demikian itu adalah karunia yang amat besar. $^{17}$

Menurut ayat di atas, Allah mewariskan Al-Qur'an kepada hamba-Nya kemudian menjadikan tiga golongan ulama. Pertama, ulama yang menganiaya diri sendiri dengan tidak menjalankan fungsi dan perannya. Kedua, ulama yang hidup sederhana dan istiqamah. Ketiga, ulama yang memelopori kebaikan, membina masyarakat, dan mendorongnya

${ }^{15}$ Ibid., hlm., 45-46

${ }^{16}$ yang dimaksud dengan Orang yang menganiaya dirinya sendiri ialah orang yang lebih banyak kesalahannya daripada kebaikannya, dan pertengahan ialah orangorang yang kebaikannya berbanding dengan kesalahannya, sedang yang dimaksud dengan orang-orang yang lebih dahulu dalam berbuat kebaikan ialah orang-orang yang kebaikannya amat banyak dan amat jarang berbuat kesalahan.

17 QS. Faathir: 32. 
dan komersil. 15). ulama yang senang membicarakan keduniaan. ${ }^{21}$

Selain itu, menurut Alfayed Shihab ada pula ulama yang b. ulama-ulama yang bisa dipertanggung jawabkan. Ulama tipe ini meliputi: 1). ulama yang penuh rasa tanggungjawab. 2). ulama yang amanah terhadap ilmu. . 3). ulama yang senantiasa rendah hati (tawadlu ${ }^{l}$ ). 4). ulama yang memiliki sifat mulia. 5). ulama yang perilakunya sesuai dengan ilmunya. 6). ulama yang menyebar-luaskan ilmunya. 7). ulama yang menghadapi kontroversi dalam penyebaran ilmu. ${ }^{22}$

\section{Peran Ulama}

Quraish Shihab dalam bukunya yang berjudul Membumikan Al-Quran menjelaskan bahwa para ulama - melalui pemahaman, pemaparan, dan pengamalan kitab suci - bertugas memberikan petunjuk dan bimbingan guna mengatasi perselisihan-perselisihan pendapat, problem-problem sosial yang hidup dan berkembang dalam masyarakat. ${ }^{23}$

Lebih lanjut Quraish Shihab menjelaskan bahwa dalam kaitan dengan pemahaman, pemaparan, dan pengamalan Kitab Suci, para nabi (khususnya Nabi Muhammad saw.) memiliki keistimewaan yang tidak dimiliki oleh para ulama, dalam arti mereka tidak dapat mewarisinya secara sempurna. Ulama menurutnya hanya sekadar berusaha untuk memahami Al-Quran scpanjang pengetahuan dan pengamalan ilmiah mereka, untuk kemudian memaparkan kesimpulan-kesimpulan mereka kepada masyarakat. Dalam usaha ini, mereka dapat saja mengalami kekeliruan ganda: pertama, pada saat memahami; dan kedua, pada saat memaparkan. Dua hal ini tidak mungkin dialami oleh Nabi Muhammad

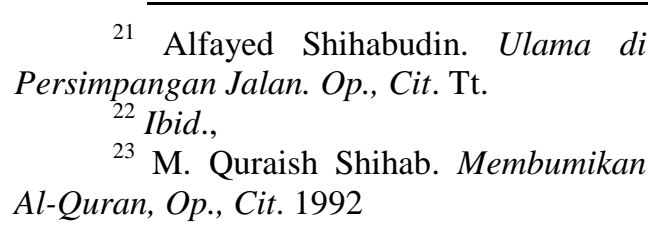

21 Alfayed Shihabudin. Ulama di Persimpangan Jalan. Op., Cit. Tt.

23 M. Quraish Shihab. Membumikan Al-Quran, Op., Cit. 1992

ditanya tentang suatu hukum yang tidak ditemukan dalilnya, ia menjawab, "Saya tidak tahu."

7. Senang kepada setiap ilmu yang dapat mendekatkan diri kepada Allah SWT. Cinta kepada musyahadah (ilmu untuk menyingkap kebesaran Allah SWT), muraqabah (ilmu untuk mencintai perintah Allah dan menjauhi laranganNya), dan optimis terhadap tahmatNya.

8. Berusaha sekuat-kuatnya mencapai tingkat haqqul-yakin. Sabda Nabi saw., "Yakin itu adalah kescmpurnaan iman.". 20

9. Senantiasa khasyyah kepada Allah, takzim atas segala kebesaran-Nya, tawadhu hidup sederhana, dan berakhlak mulia terhadap Allah maupun sesamannya.

10. Menjauhi ilmu yang dapat membatalkan amal dan kesucian hatinya.

11. Memiliki ilmu yang berpangkal di dalam hati, bukan di atas ki-tab. Ia hanya taklid kepada hal-hal yang telah diajarkan Rasulullah

Sedangkan Alfayed Shihabuddin dalam bukunya yang berjudul Ulama di Persimpangan Jalan membagi ulama kegalam a. Ulama uang menyimpang. Ulam tipe ini adalah meliputi: 1). ulama yang berhati busuk 2). ulama yang dangkal keyakinannya 3). ulama, bermental penjilat. 4). ulama yang tidak punya prinsip. 5). ulama yang memuja hawa nafsu. 6). ulama yang kepercayaan ilmunya tidak berkiblat pada golbu. 7). ulama yang memperjual belikan fatwa. 8). ulama yang suka pamer amal. 9). ulama yang menciptakan modernisasi agama. 10). ulama yang melarat amal. 11). ulama yang materialises. 12). ulama yang tidak memperhatikan kebersihanhatinya. 13). ulama yang sombong dengan ilmunya. 14). ulama yang menyembunyikan ilmu

\footnotetext{
20 (HR Baihaqi)
} 
semesta. Sedangkan pemaparan atau penyajiannya menuntut kemampuan memahami materi yang disampaikan, bahasa yang digunakan, manusia yang dihadapi, keadaan ruang dan waktu, serta kemampuan memilih saat berbicara dan saat diam. Sementara, pengalaman menuntut penjelmaan konkret isi Kitab Suci dalam bentuk tingkah laku, agar dapat menjadi panutan masyarakatnya.

\section{DAKWAH ISLAMIYYAH 1. Pengertian Dakwah}

Secara etimologis atau istilah, kata dakwah didefinisikan oleh banyak tokoh dengan berbagai pengertian (ta'rif).

a. Menurut A. Hasjmy. Dakwah Islamiyah adalah mengajak orang lain untuk meyakini dan mengamalkan aqidah dan syari'at Islam yang terlebih dahulu telah diyakini dan diamalkan oleh pendakwah sendiri. ${ }^{27}$

b. Menurut HMS. Nasarudin Latif sebagaimana dikutip oleh Moh. Ali Aziz dari buku Teori dan Praktik Dakwah Islamiyah; Dakwah adalah setiap usaha atau aktivitas dengan lisan atau tulisan yang bersifat menyeru, mengajak memanggil manusia lainnya untuk beriman dan menaati Allah Swt, sesuai dengan garis-garis aqidah dan syari'ah serta akhlak Islamiyah. ${ }^{28}$

c. Menurut Syekh Ali Mahfudz sebagaimana juga dikutip oleh Moh. Ali Aziz dari kitab Hidayatul Mursyidin dinyatakan bahwa dakwah adalah mengajak (mendorong) manusia untuk mengikuti kebenaran dan petunjuk, menyeru mereka berbuat kebajikan dan melarang mereka dari perbuatan munkar agar mereka mendapat kebahagiaan di dunia dan akhirat. $^{29}$

27 A. Hasjmy, Dustur Dakwah Op., Cit., hlm. 18.

28 Moh. Ali Aziz, Ilmu Dakwah, Jakarta, Kencana, 2004, hlm. 5.

${ }^{29}$ Ibid., hlm. 4 saw. berdasarkan firman Allah, Sesungguhnya atas tanggungan Kamilah penjelasannya, ${ }^{24}$ dan . . . Kami turunkan Al-Quran itu dengan hak dan benar, dan ia pun telah turun dengan segala kebenaran. $^{25}$ Keduanya merupakan konsekuensi logis dari jabatan kenabian dan kerasulan, seperti difirmankan Allah, Sesungguhnya Kami mengutus engkau disertai dengan segala kebenaran (dalam segala aspeknya) ${ }^{26}$

Sedangkan dalam pcngalaman, Nabi Muhammad saw. mengamalkan ajaranajaran Al-Quran secara sempurna, sehingga ajaran-ajaran tersebut menjelma dalam perilaku sehari-hari beliau. Kemampuan penjelmaan tersebut, menurut para ahli, disebabkan oleh kesempurnaan attitude (kesediaanataubakat) yang bergabung dalam tingkat yang sama dalam pribadi Nabi Muhammad saw., yakni kesediaan beribadah, berpikir, mengekspresikan keindahan, dan ber-karya. ${ }^{4}$ Kesempumaan-kesempurnaan itu kemudian dihiasi oleh kesederhanaan dalam aksi dan interaksi, lepas dari sifatsifat yang dibuat-buat atau berpura-pura.

Dengan demikian, peran yang dituntut dari para ulama adalah musabaqah bi al-khayrat (berlomba dalam berbuat kebajikan), yang titik tolaknya adalah mendekati, karena tidak mungkin mencapai, keistimewaan-keistimewaan yang dimiliki oleh orang-orang yang diwarisinya, yakni pemahaman, pemaparan, dan pengamalan Kitab Suci.

Pemahaman tersebut menuntut adanya usaha pemecahan problemproblem sosial yang dihadapi, pemecahan yang tidak mungkin dapat dicetuskan tanpa memahami metode integrasi antara wahyu dan perkembangan masyarakat dengan segala aspirasinya dan alam

\footnotetext{
${ }^{24}$ QS Al-Qiyamah :19

${ }^{25}$ QS Al-Isra : 105

${ }^{26}$ QS Al-Baqarah :105
} 
membangun kesadaran obyek dakwah maka dakwahpun harus dilakukan dengan langkah dan cara yang bijaksana.

\section{Dakwah dalam Ayat-ayat Al-Qur'an}

Al-Qur'an menyinggung masalah dakwah (secara terminologis) dalam surat;

1) An-Nahl ayat 125:

Artinya: Serulah (manusia) kepada jalan Tuhan-mu dengan hikmah, ${ }^{34}$ dan pelajaran yang baik dan bantahlah mereka dengan cara yang baik. Sesungguhnya Tuhanmu dialah yang lebih mengetahui tentang siapa yang tersesat dari jalan-Nya dan dialah yang lebih mengetahui orang-orang yang mendapat petunjuk. $^{35}$

2) Ali Imran 104:

Artinya: Dan hendaklah ada di antara kamu segolongan umat yang menyeru kepada kebajikan, menyuruh kepada yang ma'ruf, ${ }^{36}$ dan mencegah dari yang munkar; merekalah orang-orang yang beruntung. ${ }^{37}$

\section{3) Ali Imran 110:}

Artinya: Kamu adalah umat yang terbaik yang dilahirkan untuk manusia, menyuruh kepada yang ma'ruf, dan mencegah dari yang munkar, dan beriman kepada Allah. sekiranya ahli Kitab beriman, tentulah itu lebih baik bagi mereka, di antara mereka ada yang beriman, dan kebanyakan mereka adalah orang-orang yang fasik. ${ }^{38}$

\footnotetext{
${ }^{34}$ Hikmah: ialah perkataan yang tegas dan benar yang dapat membedakan antara yang hak dengan yang bathil.

${ }^{35}$ QS. An-Nahl : 125

36 Ma'ruf: segala perbuatan yang mendekatkan kita kepada Allah; sedangkan munkar ialah segala perbuatan yang menjauhkan kita dari pada-Nya.

${ }^{37}$ QS. Ali Imran :104:

${ }^{38}$ QS. Ali Imran : 110
}

d. Menurut Sayyid Quthub dakwah adalah sebuah usaha mewujudkan sistem Islam dalam kehidupan nyata dari tataran yang paling kecil, seperti keluarga, hingga yang paling besar, seperti Negara atau ummah dengan tujuan mencapai kebahagiaan dunia dan akhirat. ${ }^{30}$

e. Menurut Prof. H.M. Thoha Yahya OmarDakwah ialah mengajak manusia dengan cara bijaksana kepada jalan yang benar sesuai dengan perintah Tuhan untuk kemaslahatan dan kebahagiaan di dunia dan akhirat. ${ }^{31}$

f. Menurut Hamzah Yakub Dakwah adalah mengajak umat manusia dengan hikmah kebijak-sanaan untuk mengikuti petunjuk Allah dan RasulNya. $^{32}$

g. Menurut Masdar Helmy dakwah adalah mengajak dan menggerakkan manusia agar menaati ajaran-ajaran Allah (Islam) termasuk amr ma'ruf nahi munkar untuk bisa memperoleh kebahagiaan di dunia dan akhirat. ${ }^{33}$

Dari beberapa definisi tersebut dapat digarisbawahi bahwa pengertian dakwah adalah kegiatan menyampaikan pesan yang berisi nilai, norma, hukum agama (Islam) kepada obyek (individu, kelompok, masyarakat) agar mereka menjalankan ajaran agama dengan penuh kesadaran sehingga terwujud sistem sosial yang harmonis dan damai dan pada akhirnya mendatangkan kebahagiaan hidup di dunia dan di akhirat. Demi untuk

${ }^{30}$ A. Ilyas Ismail dan Prio Hotman, Filsafat Dakwah; Rekayasa Membangun Agama dan Per-adaban Islam, Jakarta, Kencana Prenada Media Group, 2011, hlm. 29.

31 Toha Yahya Omar, Islam dan Dakwah, Jakarta. Zakia Islami Press, 2004, hlm. 67.

32 Asmuni Syukir, Dasar-Dasar Strategi Dakwah Islam, Surabaya, Al-Ikhlas, 1983., hlm. 19.

Cit., hlm. 6.

${ }^{33}$ Moh. Ali Aziz, Ilmu Dakwah, Op., 
manusia, baik secara lisan maupun tulisan, ataupun secara lukisan. (Panggilan, seruan dan ajakan kepada manusia pada Islam).

Adapun arti Da'wah Islamiyyah dalam arti luas: adalah penjabaran, penerjemahan dan pelaksanaan Islam dalam perikehidupan dan penghidupan manusia (termasuk dalamnya: politik, ekonomi, sosial, pendidikan, ilmupengetahuan, kesenian, kekeluargaan dan lain sebagainya). (Da'wah dalam arti luas adalah seluas kehidupan dan penghidupan itu sendiri). ${ }^{41}$

\section{Tantangan Dakwah Islamiyyah}

Perkembangan global terjadi secara massif. Budaya, ekonomi: politik, pendidikan, berjalan dan berkembang secara berkelindan Satu persoalan bangsa tidak hanya dipicu oleh satu aspek saja, sehingga penyelesaiannyapun memerlukan pendekatan secara multi-disiplin.

Dalam konteks global, dakwah islamiyah mau tak mau harus dijalankan dengan membawa konsep kenegaraan. Era negara bangsa saat ini, mau tak mau, mengharuskan dakwah Islamiyah dengan mematangkah konsep kenegaraan sebagai sarana pembentukan masyarakat dan sistem Islam. Dengan demikian dapat dikatakan bahwa dakwah islamiyah dalam konteks internasional dakwah membutuhkan strategi yang bersifat sistemik. Pola kehidupan masyarakat dan sistem politik yang dijalankan dalam sebuah negara akan menentukan pola dan bahkan kemampuan dakwah umat Islam yang dalam era sekarang ini.

Dengan kata lain, konsepsi masyarakat dan negara akan menentukan suatu negara menjadi kuat atau tidak. Negara yang kuat akan dapat menjadi alat dakwah dalam konteks global. Jika negara yang dibangun umat Islam tidak kuat, maka

$41 \overline{\text { Endang Saefuddin Anshari. }}$ Wawasan Islam. Jakarta : Rajawali Pers. 1990., hlm., 190.
Dari beberapa ayat tersebut dapat ditarik benang merah bahwa dakwah adalah mengajak manusia ke jalan Allah dengan cara yang bijaksana, nasihat atau pelajaran yang baik dan berdiskusi atau berdebat dengan baik. Hikmah menurut penafsiran Departemen Agama berarti perkataan yang tegas dan benar yang dapat membedakan antara yang baik dengan yang batil. ${ }^{39}$

Berdasar pada beberapa definisi tentang dakwah tersebut di atas, Asmuni Syukir memberikan pengertian tentang dakwah sebagai berikut:

1) Dakwah adalah suatu usaha atau proses yang diselengarakan secara sadar dan terencana.

2) Usaha yang dilakukan adalah mengajak manusia ke jalan Allah, memperbaiki situasi dan kondisi menjadi lebih baik.

3) Usaha tersebut dilakukan dalam rangka mencapai kesejahteraan hidup di dunia dan akhirat. ${ }^{40}$

Dalam pengertian lebih luas dakwah dapat didefinisikan sebagai upaya menciptakan suatu kondisi dan tatanan sosial yang dilandasi oleh nilai dan ajaran Islam agar umat manusia memperoleh kebahagiaan dunia dan akhirat. Pengertian ini memberikan arahan bahwa dakwah tidak semata-mata merupakan ajakan tetapi merupa-kan rekayasa sosial yang menyangkut aspek sosial, politik, budaya, ekonomi, hukum, tata negara maupun pendidikan dalam masyarakat. Semuanya saling terkait dan tidak dapat dipisahkan.

\section{Pengertian Dakwah Islamiyyah}

Pengertian dakwah Islamiyyah bisa dilihat dari dua arti, yaitu dalam arti sempit dan dalam arti luas. Arti Da'wah Islam (Dakwah Islamiyyah) dalam arti terbatas: penyampaian Islam kepada

39 Departemen Agama RI, Al-Qur'an dan Terjemahnya, Semarang, Toha Putra, 1989, hlm. 421.

40 Asmuni Syukir, Dasar-Dasar Strategi Dakwah Islam, Op., Cit., hlm. 21. 
Begitu pula di tingkat pemerintah daerah provinsi dan kabupaten/kota telah membentuk lembaga atau satuan kerja (Satker) yang menangani khusus tentang pemberdayaan masyarakat. Banyak pula pemerintah daerah yang langsung membentuk lembaga dengan nama pemberdayaan, misalnya: Badan Pemberdayaan Masyarakat (Bapimas), atau Lembaga Pemberdayaan Masyarakat, Pada tingkat desa atau kelurahan sudah dibentuk Lembaga Pemberdayaan Masyarakat Desa atau Lembaga Pemberdayaan Masyarakat Kelurahan.

Ilmu sosial tradisional menekankan bahwa kekuasaan/ berkaitan dengan pengaruh dan kontrol. Pengertian ini mengasumsikan bahwa kekuasaan sebagai sesuatu yang tidak berubah atau tidak dapat dirubah. Kekuasaan sesungguhnya tidak terbatas pada pengertian di atas. Kekuasaan tidak vakum dan terisolasi. Kekuasaan senantiasa hadir dalam konteks relasi sosial antar manusia. Kekuasaan tercipta dalam relasi sosial. Karena itu, kekuasaan dan hubungan kekuasaan dapat berubah. Dengan pemahaman kekuasaan seperti ini, pemberdayaan sebagai sebuah proses perubahan kemudian memiliki konsep yang bermakna. Dengan kata lain, kemungkinan terjadinya proses pemberdayaan sangat tergantung pada dua hal:

1. Bahwa kekuasaan dapat berubah. lika kekuasaan tidak dapat berubah, pemberdayaan tidak mungkin terjadi dengan cara apapun.

2. Bahwa kekuasaan dapat diperluas. Konsep ini menekankan pada pengertian kekuasaan yang tidak statis, melainkan dinamis. ${ }^{44}$

Pemberdayaan menunjuk pada kemampuan orang, khusus-nya kelompok

\footnotetext{
Hikmat. Strategi Pemberdayaan

Masyarakat. Bandung Humaniora., 2013., glm., 1 44 Edi Suharto. Membangun Masyarakat., Op., cit., ., 28.
}

dakwah dalam konteks globalpun akan sulit dijalankan.

Dakwah pada hakikatnya adalah menyeru dan mengajak umat manusia untuk insaf, mengikuti kebenaran, serta mengubah keadaan menjadi lebih baik. Dakwah dalam konteks individual mensyaratkan $d a^{\prime} i$ nya untuk memiliki kekuatan, pengetahuan, keterampilan, moral, dan spiritualitas. ${ }^{42}$

D.

\section{MASYARAKAT}

1. PEMBERDAYAAN

a. Pengertian Pemberdayaan

Istilah pemberdayaan mulai tahun 1990-an menjadi trend dalam pembangunan. Kegagalan konsep pembangunan yang menekankan pada aspek makro, telah diyakini bahwa konsep pemberdayaan sebagai alternatif ampuh untuk penuntasan pembangunan. Pemerintah pusat di beberapa kementerian secara tegas membentuk berbagai lembaga pemberdayaan, bahkan ada kementerian yang mengkhususkan pada pemberdayaan perempuan. Ada juga program nasional yang fokus pada pemberdayaan yaitu Program Nasional Pemberdayaan Masyarakat-Mandiri (PNMP Mandiri). ${ }^{43}$

$42 \overline{\text { Dalam konteks global, dakwah saat }}$ ini tidak dapat dilakukan secara individual. Dakwah harus dilakukan secara kolektif, bahkan sangat mungkin menjadikan negara sebagai sarana dakwah. Sebab, banyak prinsip-prinsip kemasyarakatan yang menjadi bagian dari materi dakwah tidak dijalankan oleh orang per-orang, tetapi hanya dapat dilakukan dalam konteks negara, seperti konsep, syura (musyawarah), musawwa (kesetaraan), adalah (adil), huriy (kebebasan), amanah (trust), salam, (kedamaian), serta tasamuh (saling menghormati). Lihat Ropingi el-Ishaq. Pengantar Ilmu Dakwah Studi Komprehendif Dakwah dari Teori ke Praktik. Malang: Madani. 2016., hlm. 188

43 Oos. M. Anwas, Pemberdayaan Masyarakat di Era Global. Bandung : Alfabeta. 2014., hlm., 2. Lihat juga Harry 
d. Pemberdayaan adalah suatu cara dengan mana rakyat, organisasi, dan komunitas diarahkan agar mampu menguasai (atau berkuasa atas) kehidupannya (Rappaport, 1984).

Dengan demikian pemberdayaan adalah sebuah proses dan lujuan. Sebagai proses, pemberdayaan adalah serangkaian kegiatan untuk masyarakat, termasuk individu-individu yang mengalami masalah kemiskinan. Sebagai lujuan, maka pem-berdayaan menunjuk pada keadaan atau hasil yang ingin dicapai oleh scbuah perubahan sosial; yaitu masyarakat yang berdaya, memiliki kekuasaan atau mempunyai pengetahuan dan kemampuan dalam memenuhi kebutuhan hidupnya baik yang bersifat fisik, ekonomi, maupun sosial seperti memiliki kepercayaan diri, mampu menyampaikan aspirasi, mempunyai mata pencaharian, berpartisipasi dalam kegiatan sosial, dan mandiri dalam melaksanakan tugas-tugas kehidupannya. Pengertian pemberdayaan sebagai tujuan seringkali digunakan sebagai indikator keber-hasilan pemberdayaan sebagai sebuah proses.

\section{b. Indikator Keberdayaan}

Untuk mengetahui fokus dan tujuan pemberdayaan secara operasional, maka perlu diketahui berbagai indikator keberdayaan yang dapat menunjukkan seseorang itu berdaya atau tidak. Sehingga ketika sebuah program pemberdayaan sosial diberikan, segenap upaya dapat dikonsentrasikan pada aspek-aspek apa saja dari sasaran perubahan (misalnya keluarga miskin) yang perlu dioptimalkan.

Schuler, Hashemi dan Riley mengembangkan delapan indikator pem-berdayaan, yang mereka sebut sebagai empowerment index atau rentan dan lemah sehingga mereka memiliki kekuatan atau kemampuan dalam (a) memenuhi kebutuhan dasarnya sehingga mereka memiliki kebebasan (freedom), dalam arti bukan saja bebas mengemukakan pendapat, melainkan bebas dari kelaparan, bebas dari kebodohan, bebas dari kesakitan; (b) menjangkau sumber-sumber produktif yang memungkinkan mereka dapat meningkatkan pendapatannya dan memperoleh barang-barang dan jasa-jasa yang mereka perlukan; dan (c) berpartisipasi dalam proses pembangunan dan keputusan-keputusan yang mempengaruhi mereka.

Berikut ini pengertian pemberdayaan menurut beberapa ahli dilihat dari tujuan, proses, dan cara-cara pemberdayaan yang ditulis oleh Edi Suharto dalam bukunya yang berjudul Membangun Masyarakat memberdayakan Rakyat. ${ }^{45}$

a. Pemberdayaan bertujuan untuk meningkatkan kekuasaan orang-orang yang lemah atau tidak beruntung (Ife, 1995).

b. Pemberdayaan adalah sebuah proses dengan mana orang menjadi cukup kuat untuk berpartisipasi dalam, berbagi pengontrolan atas, dan mempengaruhi lerhadap, kejadiankejadian ini, hingga lembaga yang mau memrnuhi kehidupannya. I'emberdayaan menekankan bahwa orang memperoleh keterampilan, pengetahuan, dan kekuasaan yang cukup untuk mempengaruhi kehidupannya dan kehidupan orang lain yang menjadi perhatiannya (Parsons, et.al., 1994).

c. Pemberdayaan menunjuk pada usaha pengalokasian kembali kekuasaan melalui pengubahan struktur sosial (Swift dan Levin, 1987).

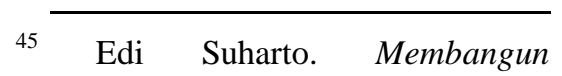
Masyarakat Ibid., 27. 
4. Terlibat dalam pembuatan keputusankeputusan rumah tangga: mampu membuat keputusan secara sendiri maupun bersama suami/istri mengenai keputusan-keputusan keluarga, misalnya mengenai renovasi rumah, pembelian kambing untuk diternak, memperoleh kreditusaha.

5. Kebebasan relatif dari dominasi keluarga: responden ditanya mengenai apakah dalam satu tahun terakhir ada seseorang (suami, istri, anak-anak, mertua) yang mengambil uang, tanah, perhiasan dari dia tanpa ijinnya; yang melarang mempunyai anak; atau melarang bekerja di luar rumah.

6. Kesadaran hukum dan politik: mengetahui nama salah seorang pegawai pemerintah desa/kelurahan; seorang anggota DPRD setempat; nama presiden; mengetahui pentingnya memiliki surat nikah dan hukumhukum waris.

7. Keterlibatan dalam kampanye dan protes-protes: seseorang dianggap 'berdaya' jika ia pernah terlibat dalam kampanye atau bersama orang lain melakukan protes, misalnya, terhadap suami yang memukul istri; istri yang mengabaikan suami dan keluarganya; gaji yang tidak adil; penyalahgunaan bantuan sosial; atau penyalahgunaan kekuasaan polisi dan pegawai pemerintah.

8. Jaminan ekonomi dan kontribusi terhadap keluarga: memiliki rumah, tanah, asset produktif, tabungan. Seseorangdianggap memiliki poin tinggi jika ia memiliki aspek-aspek tersebut secara sendiri atau terpisah dari pasangannya. ${ }^{46}$

\section{c. Strategi Pemberdayaan}

$\begin{array}{ccc}\text { Parsons } & \text { et.al. } & (1994: 112-113) \\ \text { sebagaimana dikutip } & \text { oleh } & \text { Suharto, }\end{array}$

46 Edi Suharto. Membangun

Masyarakat Ibid., hlm., 27., hlm., 218-219 indeks pemberdayaan (Suharto, 2004). Keberhasilan pemberdayaan masyarakat dapat dilihat dari keberdayaan mereka yang menyangkut kemampuan ekonomi, kemampuan mengakses manfaat kesejahteraan, dan kemampuan kultural dan politis. Ketiga aspek tersebut dikailkan dengan empat dimensi kekuasaan. Yaitu: 'kekuasaan di dalam' (power within), kekuasaan untuk (power to) 'kekuasaan atas (power over), dan 'kekuasaan dengan' (power with). Adapun indikator pemberdayaan adalah:

1. Kebebasan mobilitas: kemampuan individu untuk pergi ke luar rumah atau wilayah tempal tinggalnya, seperti ke pasar, fasilitas medis, bioskop, rumah ibadah, ke rumah tetangga. Tingkat mobilitas ini dianggap tinggi jika individu mampu pergi sendirian.

2. Kemampuan membeli komoditas kecil: kemampuan individu untuk membeli barang-barangkebutuhan keluargasehari-hari (beras, minyak tanah, minyak goreng, bumbu); kebutuhan dirinya (minyak rambut, sabun mandi, rokok, bedak, sampo). Individu dianggap mampu melaku-kan kegiatan ini terutama jika ia dapat membuat keputusan sendiri tanpa meminta ijin pasangannya; terlebih jika ia dapat membeli barangbarangtersebut dengan menggunakan uangnya sendiri.

3. Kemampuan membeli komoditas besar: kemampuan individu untuk membeli barang-barangsekunderatau tersier, seperti lemari pakaian, TV, radio, koran, majalah, pakaian keluarga. Seperti halnya indikator di atas, poin tinggi diberikan terhadap individu yang dapat membuat keputusan sendiri tanpa meminta ijin pasangannya; terlebih jika ia dapat membeli barangbarangtersebut dengan menggunakan uangnya sendiri. 
perubahan diarahkan pada sistem lingkungan yang lebih luas. Perumusan kebijakan, perencanaan sosial, kampanye, aksi sosial, lobbying, pengorganisasian masyarakat, manajemen konflik, adalah beberapa strategi dalam pendekatan ini. Strategi Sistem Besar memandang klien sebagai orang yang memiliki kompetensi untuk memahami situasi-situasi mereka sendiri, dan untuk memilih serta menentukan strategi yang tepat untuk bertindak. $^{47}$

\section{d. Pendekatan Pemberdayaan}

Pelaksanaan proses dan pencapaian tujuan pemberdayaan di atas dicapai dengan melalui penerapan pendekatan pemberdayaan yang dapat disingkat menjadi 5P, yaitu: Pemungkinan, Penguatan, Perlindungan, Penyokongan dan Pemeliharaan. ${ }^{48}$

1. Pemungkinan: menciptakan suasana atau iklim yang memungkinkan potensi masyarakat berkembang secara optimal. Pemberdayaan harus mampu membebaskan masyarakat dari sekatsekat kultural dan struktural yang menghambat.

2. Penguatan: memperkuat pengetahuan dan kemampuan yang dimiliki masyarakat dalam memecahkan masalah dan memenuhi kebutuhankebutuhannya. Pemberdayaan harus mampu menumbuhkembangkan segenap kemampuan dan kepercayaan diri masyarakat yang menunjang kemandirian mereka.

3. Perlindungan: melindungi masyarakatterutama kelompokkelompok lemah agar tidak tertindasoleh kelompok kuat, menghindari terjadinya persaingan yang tidak seimbang (apalagi tidak

$4 7 \longdiv { \text { Edi Suharto. Membangun } }$

Masyarakat Ibid., hlm., 27., hlm., 218-219

${ }^{48}$ Ibid., hlm., menyatakan bahwa proses pemberdayaan umumnya dilakukan secara kolektif. Menurutnya, tidak ada literature yang menyatakan bahwa proses pemberdayaan terjadi dalam retasi satu-lawan-satu antara pekerja sosial dan klien dalam setting pertolongan perseorangan. Meskipun pemberdayaan seperti ini dapat meningkatkan rasa percayadiri dan kemampuan diri klien, hal ini bukanlah strategi utama pemberdayaan. Namun demikian, tidak semua intervensi pekerjaan sosial dapat dilakukan melalui kolektivitas. Dalam beberapa situasi, strategi pemberdayaan dapat saja dilakukan secara individual; meskipun pada gilirannya strategi ini pun tetap berkaitan dengan kolektivitas, dalam arti mengkaitkan klien dengan sumberatau sistem lain di luardirinya. Dalam konteks pekerjaan sosial, pemberdayaan dapat di lakukan melalui tiga aras atau matra pemberdayaan (empowerment setting): mikro, mezzo, dan makro.

1. Aras Mikro. Pemberdayaan dilakukan terhadap klien secara individu melalui bimbingan, konseling, stress management, crisis intervention. Tujuan utamanya adalah membimbing atau melatih klien dalam menjalankan tugas-tugas kehidupannya. Model ini sering disebut sebagai Pendekatan yang Berpusat pada Tugas (task centered approach).

2. Aras Mezzo. Pemberdayaan dilakukan terhadap sekelompok klien. Pemberdayaan dilakukan dengan menggunakan kelompok sebagai media intervensi. Pendidikan dan pelatihan, dinamika kelompok, biasanya digunakan sebagai strategi dalam mcmngkatkan kesadaran, pengetahuan, keterampilan dan sikap-sikap klien agar memiliki kemampuan memecahkan permasalahan yang dihadapinya.

3. Aras Makro. Pendekatan ini disebut juga sebagai Strategi Sistem Besar (large-system strategy), karena sasaran 
kesempatan belajar; (d) melibatkan klien dalam pembuatan keputusan dan evaluasi.

4. Merefleksikan sikap dan nilai profesi pekerjaan sosial melalui: (a) ketaatan terhadap kode etik profesi; (b) keterlibatan dalam pengembangan profesional, riset, dan perumusan kebijakan; (c) penerjemahan kesulitankesulitan pribadi ke dalam isu-isu publik; (d) penghapusan segala bentukdiskriminasi dan ketidaksetaraan kesempatan. ${ }^{49}$

\section{DAFTAR BACAAN}

Alfayed Shihabudin. Ulama di Persimpangan Jalan: Dilema Persoalan Ulama Abad Modern Antara jalan Ilahiyyah dan Nafsu. Jombang: Lintas Media. Tt.

Badruddin HSubky. Dilema Ulama dalam Perubahan Zxmqn Jakarta: Gema Insani Press. 1995.

Bambang Rustanto. Menangani Kemiskinan. Bandung: Prenada Rosda Karya. 2015.

Edi Suharto. Membangun Masyarakat Memberdayakan Rakyat: Kajian Strategis Pembangunan Kesejahteraan Sosial \& Pekerjaan Sosial, Bandung: PT. Refika Aditama. 2013.

Endang Syarifuddin Anshari. Wawasan Islam: Pokok-Pokok Pikiran tentang Islam dan Ummatnya, Jakarta: Rajawali Press. 1990.

49

Edi Suharto. Pembangunan Kebijakan sosial dan Pekerjaan sosial; Spektrum Pemikiran : Bandung ; Lembaga Studi Pembangunan STKS (LSP-STKS). 1996., hlm., 68 sehat) antara yang kuat dan lemah, dan mencegah terjadinya eksploitasi kelompok kuat terhadap kelompok lemah. Pemberdayaan harus diarahkan pada penghapusan segala jenis diskriminasi dan dominasi yang tidak menguntungkan rakyat kecil.

4. Penyokongan: memberikan bimbingan dan dukungan agar masyarakat mampu menjalankan peranan dan tugas-tugas kehidupannya. Pem-berdayaan harus mampu menyokong masyarakat agar tidak lerjatuh ke dalam keadaan dan posisi yang semakin lemah dan terpinggirkan.

5. Pemeliharaan: Memelihara kondisi yang kondusif agar tetap terjadi keseimbangan distribusi kckuasaan antara berbagai kelompok dalam masyarakat. Pemberdayaan harus mampu menjamin keselarasan dan keseimbangan yang memungkinkan setiap orang memperoleh kesempatan berusaha.

Adapun teknik pemberdayaan yang dapat dilakukan untuk mem-berdayakan masyarakat menurut Dubois dan Miley (1992:211) sebagaimana dikutip Suharto adalah;

1. Membangun relasi pertolongan yang: (a) merefleksikan respon empati; (b) menghargai pilihan dan hak klien menentukan nasibnya sendiri (selldetermination); (c) menghargai perbedaan dan keunikan individu; $(d)$ menekankan kerjasama klien \{client partnerships).

2. Membangun komunikasi yang: (a) menghormati martabat dan harga diri klien; (b) mempertimbangkan kcragaman individu; (c) berfokus pada klion; $(d)$ menjaga kerahasiaan klien.

3. Terlibat dalam pcmecahan masalah yang: (a) memperkuat parti si pasi klien dalam semua aspek proses pemecahan masalah; (b) menghargai hak-hak klien; (c) merangkai tantangan-Lantangan sebagai 
Enjang AS dan Hajir Tajiri. Etika Dakwah: Suatu Pendekatan Teologis dan Filosofis Bandung: Widya padjajaran. 2009.

Hajiri Tajiri. Etika dan Estetika DakwahPrespektif Teologis, Filosofis dan praktis, Kairo: Bandung: Simbiosa Rekatama Media. 2015.

Harry Hikmat. Strategi Pemberdayaan Masyarakat, Bandung : Humaniora Utama Press. 2013.

M. Quraish Shihab. Membumikan AlQuran: Fungsi dan Peran Wahyu dalam Kehidupan Masyarakat. Bandung: Mizan. 1992.

Moh Ali Aziz, dkk (Ed). Dakwah Pemberdayaan Masyarakat Paradigma Aksi Metodologi. Yogyakarta: Pustaka Pesantren. 2005.

Oos. M. Anwas, Pemberdayaan Masyarakat di Era Global. Bandung: Alfabeta. 2014.

Ropingi el-Ishaq. Pengantar Ilmu Dakwah Studi Komprehendif Dakwaj dari Teori ke Praktik. Malang: Madani. 2016.

Saefullah Ma'shum. Dinamika Pesantren: Telaah Kritis Keberadaan Pesantren Saat Ini. Depok: Yayasan Islam Al-Hamidiyyah dan Yayasan Saefuddin Zuhri, 1998.

Totok Hardi Kanto dan Poerwoko Soebiato. Pemberdayaan Masyarakat dalam Psrespektif Kebijakan Publik, Bandung: Alfabeta. 2013. 